\title{
Whole-Body Leucine Kinetics and the Acute Phase Response during Acute Infection in Marasmic Malawian Children
}

\author{
MARK J. MANARY, KEVIN E. YARASHESKI, RICHARD BERGER, ELIZABETH T. ABRAMS, \\ CHARLES ANTHONY HART, AND ROBIN L. BROADHEAD
}

\begin{abstract}
Departments of Pediatrics [M.J.M.] and Internal Medicine [K.E.Y., R.B.], Washington University School of Medicine, St. Louis, MO 63110, U.S.A.; Department of Anthropology [E.T.A.], University of Michigan, Ann Arbor, MI 48109, U.S.A.; Department of Medical Microbiology [C.A.H.], University of Liverpool, Liverpool L69 3GA, United Kingdom; and College of Medicine [M.J.M., R.L.B.], University of Malawi,
\end{abstract}

Private Bag 360, Blantyre 3, Malawi

\begin{abstract}
This study compared leucine kinetics and acute-phase protein and cytokine concentrations in three groups of Malawian children who were fed an isoenergetic, isonitrogenous diet: children with marasmus with $(n=25)$ and without $(n=17)$ infection and well-nourished children with infection $(n=13)$. The hypotheses tested were that whole-body leucine kinetics will be less in marasmic acutely infected children than in well-nourished acutely infected children but greater than in marasmic uninfected children. Children were studied after $24 \mathrm{~h}$ of therapy using standard ${ }^{13} \mathrm{C}$-leucine stable isotope tracer techniques. Wellnourished children with acute infection had greater leucine kinetic rates than did marasmic children with acute infection; nonoxidative leucine disposal was $153 \pm 31$ versus $118 \pm 43$ $\mu$ mol leucine $\cdot \mathrm{kg}^{-1} \cdot \mathrm{h}^{-1}$, leucine derived from whole-body proteolysis was $196 \pm 34$ versus $121 \pm 47$, and leucine oxidation was $85 \pm 31$ versus $45 \pm 13$ ( $p<0.01$ for all comparisons).
\end{abstract}

\section{ABSTRACT}

Leucine kinetic rates were similar in marasmic children with and without acute infection. Well-nourished children with acute infection increased their serum concentration of five of six acutephase proteins during the first $24 \mathrm{~h}$, whereas marasmic children with infection did not have any increases. The serum concentrations of IL-6 were elevated in well-nourished and marasmic children with infection. These data suggest that the cytokine stimulus for the acute-phase protein kinetic response to acute infection is present in marasmic children but that the acute-phase protein metabolic response is blunted by malnutrition. (Pediatr Res 55: 940-946, 2004)

\section{Ra, rate of appearance \\ TNF- $\alpha$, tumor necrosis factor- $\alpha$}

Abbreviations
Severe malnutrition and acute systemic infection are often coincident and synergistic in children (1). In adults, these two physiologic states are important determinants of whole-body protein kinetics. Whole-body protein kinetics are characterized by the dynamic sum of factors that add to the free amino acid pool, primarily dietary protein intake and the release of amino acids during proteolysis, and those factors that subtract from this pool, namely the use of amino acids in the synthesis of new protein and the oxidation of amino acids (2). Protein synthesis is limited by the availability of free amino acids, and muscle

Received July 10, 2003; accepted November 20, 2003.

Correspondence: Mark J. Manary, M.D., Department of Pediatrics, Washington University School of Medicine, St. Louis Children's Hospital, One Children's Place, St. Louis, MO 63110, U.S.A.; e-mail: manary@kids.wustl.edu

Supported by National Institutes of Health (RO1HD38422), the Washington University Biomedical Mass Spectrometry Facility (NIH RR00954), and Clinical Nutrition Research Unit (NIH P30 DK56341).

DOI: 10.1203/01.pdr.0000127017.44938.6d proteolysis can be accelerated to increase the pool of free amino acids. Malnutrition decreases protein turnover by lowering dietary intake of amino acids and limiting proteolysis to conserve amino acids (3). Acute infection increases protein turnover (4) by invoking the acute-phase response, the accelerated synthesis of a group of proteins useful to the host in successfully responding to the infection $(5,6)$. Understanding how malnutrition and acute infection together affect protein metabolism in children may give insight into the optimum dietary therapy to facilitate recovery, as well as increase the knowledge of the interaction between nutritional status and immunity.

Unfortunately, little is known about these relationships, primarily because of the complexity and challenges in measuring protein kinetics in young children. In addition, primary malnutrition usually occurs in poor populations in the developing world, far removed from the clinical research units where protein kinetics are often studied. This study used a 
standard ${ }^{13} \mathrm{C}$-leucine stable isotope tracer dilution method to measure whole-body leucine kinetics (7) in Malawian children with marasmus with and without acute infection and compares them with well-nourished Malawian children with acute infection. The hypotheses tested were that nonoxidative leucine disposal and leucine derived from whole-body proteolysis would be less in marasmic acutely infected children than in well-nourished acutely infected children but greater than in marasmic uninfected children. In addition, the magnitude of the cytokine and the acute-phase response was measured and compared in these groups of children.

\section{METHODS}

Subjects. Children who were aged 12-60 mo and had marasmus and were admitted to Queen Elizabeth Central Hospital in Blantyre, Malawi, were eligible. Marasmus was defined as having weight-for-age $<60 \%$ of the international standard (8) and evidence of wasting, manifest by weight-for-height $<80 \%$ of the international standard. After mothers gave their informed consent for their child's participation, each child was admitted to a special metabolic ward, which provided more intensive nursing care, better parenteral antibiotics, more frequent feedings, and more careful clinical monitoring than the hospital ward. The initial evaluation of these children included blood culture, urine culture obtained by sterile catheter, chest $\mathrm{x}$-ray, thick blood smear for malaria parasites, and an ELISA for HIV (Vironostika HIV; Organon Teknika, Durham, NC, U.S.A.). Every child received parenteral ceftriaxone for the first $48 \mathrm{~h}$ after admission. Acute infection was defined as sepsis, malaria, or pneumonia. Sepsis was defined as clinical signs of sepsis with a positive blood or urine culture, malaria was defined as clinical signs of falciparum malaria with a positive smear for malaria parasites, and pneumonia was defined as cough and tachypnea with a focal infiltrate on chest x-ray. The infections were believed to be acute because according to the caregiver's report, each child's clinical condition had worsened within the day before admission. As a comparison group, children who had weight-for-age within the norms of the World Health Organization's reference population and acute infection and received the same diet as the malnourished children were enrolled. The study was approved by the Human Studies Committee of Washington University (St. Louis, MO, U.S.A.) and the College of Medicine Research Committee of the University of Malawi.

Diet. The metabolic ward diet provided $350 \mathrm{~kJ} \cdot \mathrm{kg}^{-1} \cdot \mathrm{d}^{-1}$ (85 kcal) and $1.2 \mathrm{~g} \cdot \mathrm{kg}^{-1} \cdot \mathrm{d}^{-1}$ of protein to all children. Each feeding contained $40 \mathrm{~g}$ of full-cream milk powder, $40 \mathrm{~g}$ of maize oil, and $26 \mathrm{~g}$ of sugar mixed in $1 \mathrm{~L}$ of water. All children received a mineral multivitamin supplement added to the feeding (Nutriset, Malauney, France) (9). Feedings were administered in equal amounts per kilogram of body weight every $2 \mathrm{~h}$, and children who were unable to take feedings by mouth were fed through a nasogastric tube. The diet provided modest amounts of energy and protein to meet maintenance requirements in accordance with standard recommendations for the first phase of treatment of severe malnutrition (10).
Metabolic study. The protocol and calculations for the metabolic study have been described and validated previously from a subset of the children included in this report $(11,12)$. Briefly, at $19 \mathrm{~h}$ after admission, each child's $\mathrm{CO}_{2}$ appearance rate was determined with a primed $(2.5 \mu \mathrm{mol} / \mathrm{kg})$, constant $(5$ $\mu \mathrm{mol} \cdot \mathrm{kg}^{-1} \cdot \mathrm{h}^{-1}$ ) 70-min infusion of ${ }^{13} \mathrm{C}$-sodium bicarbonate (99\% ${ }^{13} \mathrm{C}$; Cambridge Isotopes, Andover, MA, U.S.A.). Before the ${ }^{13} \mathrm{C}$-sodium bicarbonate infusion was started, breath samples were collected using a silicone rubber face mask connected to a nondiffusing gas collection bag (Hans Rudolph, Kansas City, MO, U.S.A.) to determine the baseline ${ }^{13} \mathrm{CO}_{2}$ isotope abundance. Breath samples were collected 60,65 , and $70 \mathrm{~min}$ after the initiation of the ${ }^{13} \mathrm{C}$-sodium bicarbonate infusion for the measurement of the $\mathrm{CO}_{2}$ appearance rate. Immediately after the collection of these breath samples, a primed constant i.v. infusion of $1-{ }^{13} \mathrm{C}$-leucine $\left(99 \%{ }^{13} \mathrm{C}\right)$ was begun. Each child received $1-^{13} \mathrm{C}$-leucine (prime $15.3 \mu \mathrm{mol} /$ $\mathrm{kg}$, infusion $4 \mu \mathrm{mol} \cdot \mathrm{kg}^{-1} \cdot \mathrm{h}^{-1}$ ) for $5 \mathrm{~h}$. During the $5-\mathrm{h}$ infusion, children received feedings in small aliquots every 30 min. The amount of each feed was such that it provided the same rate of dietary energy intake $\left(350 \mathrm{~kJ} \cdot \mathrm{kg}^{-1} \cdot \mathrm{d}^{-1}\right)$ as the 2-h feedings. This was done so that the metabolic measurements would be representative of the fed state rather than the postabsorptive state. At 4.5 and $5 \mathrm{~h}$ after the start of the leucine infusion, $24 \mathrm{~h}$ after admission and the initiation of feedings, a 1-mL blood sample was drawn to measure isotopic abundance of $\alpha$-ketoisocaproic acid. Three breath samples were collected $4.5,4.75$, and $5 \mathrm{~h}$ after the start of the leucine infusion for the measurement of ${ }^{13} \mathrm{CO}_{2}$ isotope abundance, representative of leucine oxidation.

Sera for the measurement of the concentrations of six acutephase proteins, C-reactive protein, properdin factor B, C3, haptoglobin, $\alpha_{1}$-antitrypsin, and $\alpha_{1}$-acid glycoprotein, and the cytokines IL- $1 \beta$, IL-6, and tumor necrosis factor- $\alpha$ (TNF- $\alpha$ ) were drawn on admission and 24 and $48 \mathrm{~h}$ after admission.

Sample analyses. In 10-mL aliquots of breath, ${ }^{13} \mathrm{CO}_{2} /{ }^{12} \mathrm{CO}_{2}$ abundance was measured using an automated gas isotope ratio mass spectrometer (Finnigan MAT Delta + XL, Bremen, Germany) (13).

Plasma $\alpha$-ketoisocaproic acid, the intracellular deamination product of leucine, was used to estimate intracellular ${ }^{13} \mathrm{C}$ leucine enrichment. Serum samples were analyzed by gas chromatography electron impact-quadruple mass spectrometry (Agilent Technologies $6890 \mathrm{~N}$ capillary GC system and 5973 Network Mass Selection Detector, Foster City, CA, U.S.A.) after the $\alpha$-ketoisocaproic acid was converted to its quinoxalinol trimethylsilyl derivative (14).

The concentrations of acute-phase proteins were measured by rate nephelometry (Beckmann Image Nephelometry System; Beckmann, High Wycombe, UK). The cytokines were measured by ELISAs that use panels of MAb to capture the individual cytokine (Bioscience, Nivelles, Belgium, and R \& D Systems, Minneapolis, MN, U.S.A.).

Calculations and statistics. The rates of appearance (Ra) of leucine and $\mathrm{CO}_{2}$ calculated from the following equation, derived from a simple mass balance (7): $\mathrm{Ra}=[(\mathrm{Ei} / \mathrm{Ep})-1] \times$ $\mathrm{I}$, where $\mathrm{Ei}$ is the isotopic enrichment of the tracer infused 
(99\%), Ep is the isotopic enrichment of the tracer in serum or breath, and $\mathrm{I}$ is the infusion rate of the tracer.

The rate of leucine oxidation $\left(\mathrm{Ra}_{\text {leuox }}\right)$ was estimated from the following equations.

$\mathrm{Ra}_{\text {leuox }}=\left(\right.$ rate of ${ }^{13} \mathrm{CO}_{2}$ appearance in breath $) \times($ fraction of leucine that is labeled with $\left.{ }^{13} \mathrm{C}\right) / 0.81$

$\mathrm{Ra}_{\text {leuox }}=\left(\mathrm{Ra}_{\mathrm{CO} 2}\right)\left({ }^{13} \mathrm{CO}_{2}\right.$ enrichment in breath $)(\mathrm{Ei} / \mathrm{Ep}-1) / 81$

where $\mathrm{Ei}$ is the isotopic enrichment of the leucine infused (98-99\%) and Ep is the isotopic enrichment of the $\alpha$-ketoisocaproic acid in plasma. The factor 0.81 accounts for the fraction of $\mathrm{CO}_{2}$ that is produced by leucine oxidation but not released from the body bicarbonate pool into the breath as determined by Matthews et al. (7).

Leucine derived from whole-body proteolysis was calculated by subtracting the rate of leucine provided in the diet and isotope infusion from $\mathrm{Ra}_{\mathrm{Leu}}$, and nonoxidative leucine disposal was calculated by subtracting $\mathrm{Ra}_{\text {leuox }}$ from $\mathrm{Ra}_{\mathrm{Leu}}$. Leucine derived from whole-body proteolysis and nonoxidative leucine disposal are indices of whole-body proteolysis and protein synthesis, respectively.

The estimated sample size was 13 children in each group, assuming that protein kinetics would vary similarly as children with kwashiorkor (14) and that differences of $10 \%$ between groups would be detected with $95 \%$ specificity and $80 \%$ power. Data are expressed as means \pm SD. Anthropometric $z$ scores were calculated using Epi Info 2000 (World Health Organization/Centers for Disease Control and Prevention, Atlanta, GA, U.S.A.). ANOVA was used to compare leucine kinetics, acute-phase proteins, and cytokines between groups of children and to compare acute-phase proteins and cytokines within groups over time. Backward multiple linear regression of the rates of nonoxidative leucine disposal, leucine derived from whole-body proteolysis, and leucine oxidation with respect to age, sex, anthropometric measurements and indices, and HIV infection was used to determine which of these parameters significantly influenced protein metabolism for malnourished children (SPSS Professional edition for Windows version 10, Chicago, IL, U.S.A.). Statistical differences of $p<0.05$ were considered to be significant.

\section{RESULTS}

Fifty-five children were studied between August 2000 and October 2001: 22 boys and 33 girls (Table 1). The constant
${ }^{13} \mathrm{C}$-sodium bicarbonate infusion reached an isotopic steady state for ${ }^{13} \mathrm{CO}_{2}$ after $55 \mathrm{~min}$ and the ${ }^{13} \mathrm{C}$-leucine infusion after $4 \mathrm{~h}$ as previously documented in a subset of these children $(11,12)$.

Leucine kinetics. The rates of nonoxidative leucine disposal, leucine derived from whole-body proteolysis, and leucine oxidation were greater in well-nourished children with acute infection than in malnourished children with or without infection (Fig. 1). Leucine kinetics were similar between marasmic children with and without infection. Although the sample size was inadequate to detect differences of $<10 \%$ between these groups, a post hoc power calculation indicated that marasmic children with acute infection were unlikely to have leucine kinetics that were $10 \%$ greater than their uninfected counterparts $(91 \%$ power). The only demographic or anthropometric characteristic that was associated with nonoxidative leucine disposal or leucine derived from whole-body proteolysis was weight-for-height $z$ score $(r=0.37, p<0.001$ for nonoxidative leucine disposal and $r=0.57, p<0.001$ for leucine derived from whole-body proteolysis). Likewise, linear regression modeling found that weight-for-height $z$ score was the only clinical characteristic that made a significant contribution.

Acute-phase proteins. Well-nourished children with acute infection had higher concentrations of C-reactive protein, $\mathrm{C} 3$, and properdin factor $\mathrm{B}$ than malnourished children with acute infection (Table 2). Malnourished children with acute infection had a greater concentration of C-reactive protein than malnourished, uninfected children. In well-nourished children with acute infection, five of the six acute-phase protein concentrations (C-reactive protein, C3, properdin factor $\mathrm{B}$, haptoglobin, and $\alpha_{1}$-acid glycoprotein) increased from admission to $24 \mathrm{~h}(p<0.05)$. For the marasmic children with acute infection, there were no significant differences in the concentration of any of the acute-phase proteins when those on admission were compared with 24-h measurements.

Cytokines. IL-6 concentrations were increased on admission in the marasmic and well-nourished children with acute infection (Table 3). IL-6 concentrations were actually greater in marasmic infected children when compared with wellnourished infected children at 24 and $48 \mathrm{~h}$. Among the wellnourished children with acute infection, the concentration of IL-6 correlated with the concentrations of C-reactive protein, C3, $\alpha_{1}$-acid glycoprotein, and $\alpha_{1}$-antitrypsin. Among the ma-

Table 1. Demographic, anthropometric, and clinical characteristics of study children

\begin{tabular}{lccc}
\hline & $\begin{array}{c}\text { Well-nourished with acute infection } \\
(\mathrm{M}=6, \mathrm{~F}=7)\end{array}$ & $\begin{array}{c}\text { Marasmic with acute infection } \\
(\mathrm{M}=8, \mathrm{~F}=17)\end{array}$ & $\begin{array}{c}\text { Marasmic without acute } \\
\text { infection }(\mathrm{M}=8, \mathrm{~F}=9)\end{array}$ \\
\hline Age (mo) & $31 \pm 14$ & $31 \pm 12$ & $28 \pm 13$ \\
Weight-for-age $z$ score & $-0.7 \pm 0.9^{*}$ & $-4.1 \pm 0.6$ & $-4.0 \pm 0.6$ \\
Height-for-age $z$ score & $0.5 \pm 1.1^{*}$ & $-3.4 \pm 1.0$ & $-3.3 \pm 1.1$ \\
Weight-for-height $z$ score & $-1.1 \pm 0.7^{*}$ & $-2.9 \pm 0.6$ & $-2.8 \pm 1.0$ \\
Clinical infections & Pneumonia-5 & Pneumonia-12 & Sepsis-8 \\
& Sepsis-2 & Malaria-10 & \\
& Malaria-9 & & \\
& &
\end{tabular}

Values are means $\pm \mathrm{SD}$

Marasmus was defined as having weight-for-age $<60 \%$ of the international standard (8) and evidence of wasting, manifest by weight-for-height $<80 \%$ of the international standard. Well-nourished was defined as having weight-for-age within the norms of the World Health Organization's reference population. For clinical infections, the number of children listed with each infection is given; some children had more than one infection.

* Greater than marasmic children, $p<0.001$. 

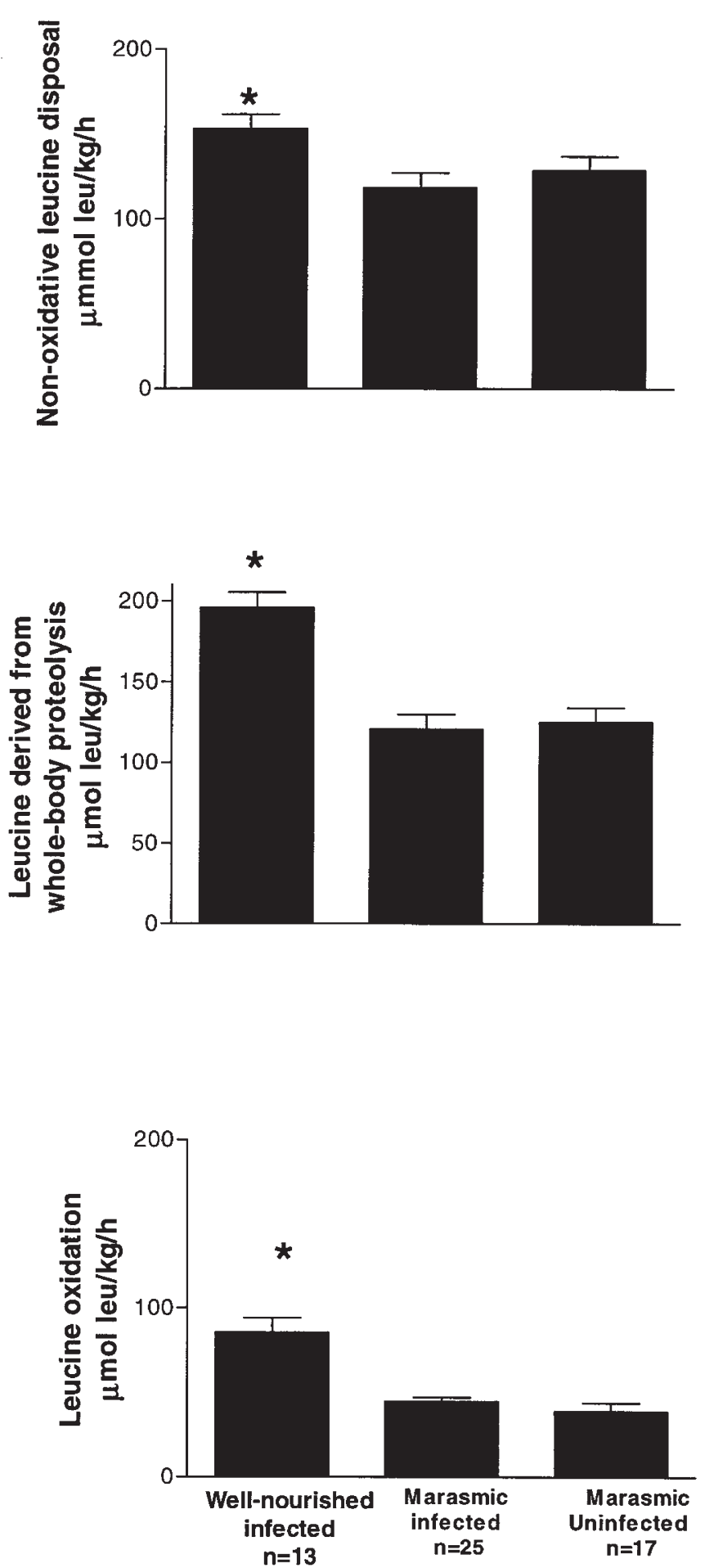

Figure 1. Mean rates of nonoxidative leucine disposal, leucine derived from whole-body proteolysis, and leucine oxidation ( \pm SEM) in three groups of Malawian children, marasmic children with and without acute infection, and well-nourished children with acute infection. ${ }^{*}$ Greater than the two marasmic groups, ANOVA, $p<0.01$.

rasmic children with acute infection, the concentration of IL-6 correlated with the concentrations of C-reactive protein, C3, $\alpha_{1}$-acid glycoprotein, and properdin factor B. Although all of these correlations were statistically significant, the slopes of the regression lines for the well-nourished children were greater than for the marasmic children, as illustrated for C-re- active protein (Fig. 2). Thus, the amount of acute-phase protein present for a given level of IL-6 was greater in well-nourished when compared with marasmic children. The pattern of serum TNF- $\alpha$ concentration was similar to that of IL-6, with little seen in uninfected children and decreasing amounts seen with time in well-nourished and malnourished children with acute infection (Table 3).

IL- $1 \beta$ showed a much different pattern than IL- 6 or TNF- $\alpha$; it was found in very low concentrations in well-nourished infected children and in elevated concentrations in malnourished children with and without infection. The malnourished children with acute infection had greater IL- $1 \beta$ concentrations than uninfected children. There was no evidence that HIV status independent of acute infection affected any of the serum cytokine measurements when tested by backward regression. Comparing the IL- $1 \beta$ concentration of HIV-negative uninfected malnourished children with HIV-positive uninfected malnourished children showed very little difference: all of the measures were $>20 \mathrm{pg} / \mathrm{mL}$, and the means were $1189 \pm 1356$ versus $802 \pm 1063$, respectively $(p=0.58)$. IL- $1 \beta$ and IL-6 concentrations were directly correlated $(r=0.47, p<0.001)$.

\section{DISCUSSION}

Marasmus depresses leucine kinetics during acute infection and is associated with lower rates of nonoxidative leucine disposal, leucine derived from whole-body proteolysis, and leucine oxidation. Marasmus is also associated with an attenuated acute-phase response but not a diminished cytokine response to acute infection.

This study assumes that whole-body leucine kinetics mirror whole-body protein kinetics, an assumption that has been made in a variety of human metabolic investigations. Leucine solutions for human infusion are safe, easy to prepare, and stable (15). Clinical methods for their administration are robust. Kinetic calculations using leucine enrichments are relatively straightforward, because leucine is an essential amino acid that is degraded via a singular pathway (7). As an isotope, ${ }^{13} \mathrm{C}$ leucine is inexpensive, and the laboratory methods for its analyses are standardized and simple. The fraction of leucine in a typical mixture of acute-phase proteins is $10.5 \%$, so leucine turnover is substantial during acute infection (16). This is why we chose leucine as the stable isotope tracer for this study and why we believe that leucine kinetics mirror whole-body protein kinetics in malnutrition and acute infection. Because of the modest content of aromatic amino acids in muscle, the primary source of amino acids during catabolism, and the relative abundance of these amino acids in acute-phase proteins, they are in tight economy during acute infection (16). Kinetic studies with aromatic amino acid tracers might yield interesting insights into protein metabolism during malnutrition and infection, but the complexity of methods precluded their use in a modest metabolic unit in Malawi. A limitation of the study is that we measured simply the concentrations of acute-phase proteins and cytokines, whereas others have measured the actual rate of synthesis (17). This would have required longer isotope infusions and much larger amounts of blood to be 
Table 2. Acute-phase protein concentrations

\begin{tabular}{|c|c|c|c|}
\hline Acute-phase protein & $\begin{array}{l}\text { Well-nourished children } \\
\text { with acute infection } \\
\qquad(n=13)\end{array}$ & $\begin{array}{l}\text { Marasmic children } \\
\text { with acute infection } \\
\quad(n=25)\end{array}$ & $\begin{array}{l}\text { Marasmic children } \\
\text { without acute infection } \\
\qquad(n=17)\end{array}$ \\
\hline \multicolumn{4}{|l|}{ C-reactive protein $(\mathrm{mg} / \mathrm{L})$} \\
\hline After $24 \mathrm{~h}$ & $132 \pm 90$ & $63 \pm 58 * \dagger$ & $23 \pm 34$ \\
\hline After $48 \mathrm{~h}$ & $78 \pm 62$ & $39 \pm 37 * \dagger$ & $14 \pm 14$ \\
\hline \multicolumn{4}{|l|}{ C3 (g/L) } \\
\hline After $48 \mathrm{~h}$ & $1.37 \pm 0.63$ & $0.73 \pm 0.40^{*}$ & $0.89 \pm 0.41$ \\
\hline \multicolumn{4}{|l|}{ Properdin factor B $(\mathrm{g} / \mathrm{L})$} \\
\hline On admission & $0.69 \pm 0.18$ & $0.42 \pm 0.17 *$ & $0.41 \pm 0.14$ \\
\hline After $24 \mathrm{~h}$ & $0.87 \pm 0.43$ & $0.41 \pm 0.15^{*}$ & $0.43 \pm 0.20$ \\
\hline After $48 \mathrm{~h}$ & $0.82 \pm 0.38$ & $0.39 \pm 0.15^{*}$ & $0.39 \pm 0.15$ \\
\hline \multicolumn{4}{|l|}{ Haptoglobin $(\mathrm{g} / \mathrm{L})$} \\
\hline On admission & $2.3 \pm 0.6$ & $2.6 \pm 0.4$ & $2.4 \pm 0.5$ \\
\hline After $24 \mathrm{~h}$ & $3.1 \pm 1.0$ & $2.6 \pm 0.4$ & $2.5 \pm 0.4$ \\
\hline After $48 \mathrm{~h}$ & $2.6 \pm 0.8$ & $2.5 \pm 0.5$ & $2.5 \pm 0.5$ \\
\hline \multicolumn{4}{|l|}{$\alpha_{1}$-Antitrypsin $(\mathrm{g} / \mathrm{L})$} \\
\hline On admission & $2.4 \pm 0.6$ & $2.3 \pm 0.6$ & $2.1 \pm 0.6$ \\
\hline After $24 \mathrm{~h}$ & $2.5 \pm 0.9$ & $2.3 \pm 0.6$ & $2.1 \pm 0.6$ \\
\hline After $48 \mathrm{~h}$ & $2.6 \pm 1.1$ & $2.3 \pm 0.6$ & $2.0 \pm 0.5$ \\
\hline
\end{tabular}

Values are means $\pm \mathrm{SD}$.

$\dagger$ Marasmus was defined as having weight-for-age $<60 \%$ of the international standard (8) and evidence of wasting, manifest by weight-for-height $<80 \%$ of the international standard. Well-nourished was defined as having weight-for-age within the norms of the World Health Organization's reference population. The concentrations of C-reactive protein, C3, properdin factor B, haptoglobin, and $\alpha_{1}$-acid glycoprotein for well-nourished, infected children showed an increase from admission to $24 \mathrm{~h}(p<0.05)$; however, among malnourished infected children, there were no increases in any of the values from admission to $24 \mathrm{~h}$.

* Less than well-nourished children, $p<0.05$.

$\dagger$ Greater than marasmic children without infection, $p<0.05$.

Table 3. Cytokine concentrations

\begin{tabular}{|c|c|c|c|}
\hline Cytokine & $\begin{array}{l}\text { Well-nourished children with } \\
\text { acute infection }(n=13)\end{array}$ & $\begin{array}{l}\text { Marasmic children with } \\
\text { acute infection }(n=25)\end{array}$ & $\begin{array}{l}\text { Marasmic children without } \\
\text { acute infection }(n=17)\end{array}$ \\
\hline \multicolumn{4}{|l|}{ IL 6 (pg/mL) } \\
\hline On admission & $87(30,482)$ & $154(62,238) \dagger$ & $<20(<20,85)$ \\
\hline After $48 \mathrm{~h}$ & $<20(<20,26)$ & $43(<20,120)^{* \dagger}$ & $<20(<20,31)$ \\
\hline \multicolumn{4}{|l|}{ TNF- $\alpha(\mathrm{pg} / \mathrm{mL})$} \\
\hline On admission & $85(<20,150)$ & $121(68,251) \dagger$ & $<20(<20,87)$ \\
\hline \multicolumn{4}{|l|}{ IL-1 $\beta(\mathrm{pg} / \mathrm{mL})$} \\
\hline On admission & $<20(<20,<20)$ & $1855(370,>3333) * \dagger$ & $393(75,751)$ \\
\hline After $24 \mathrm{~h}$ & $<20(<20,<20)$ & $692(170,1606)^{* \dagger}$ & $129(<20,306)$ \\
\hline After $48 \mathrm{~h}$ & $<20(<20,<20)$ & $145(<20,894)^{*}$ & $128(<20,236)$ \\
\hline
\end{tabular}

Data are expressed as median $(25 \%, 75 \%)$

* Greater than well-nourished children with infection, $p<0.05$.

$\dagger$ Greater than marasmic uninfected children, $p<0.05$.

drawn from the subjects, which unfortunately was not possible in our context.

Leucine kinetic parameters were normalized to body weight in this study, which is appropriate when children of similar body composition are being compared. However, marasmic and wellnourished children are not of similar body composition; the marasmic child has a larger fraction of lean body mass, which is metabolically more active. Although we found remarkable differ- ences between the malnourished and well-nourished children normalizing kinetic parameters to body weight, these differences may underestimate the degree that malnutrition suppresses protein kinetics. Normalization with a factor that accounts for body composition, such as fat-free mass, might better estimate the degree that malnutrition depresses protein turnover. The association between more severe wasting and lower rates of nonoxidative leucine disposal, leucine derived from whole-body proteolysis, 


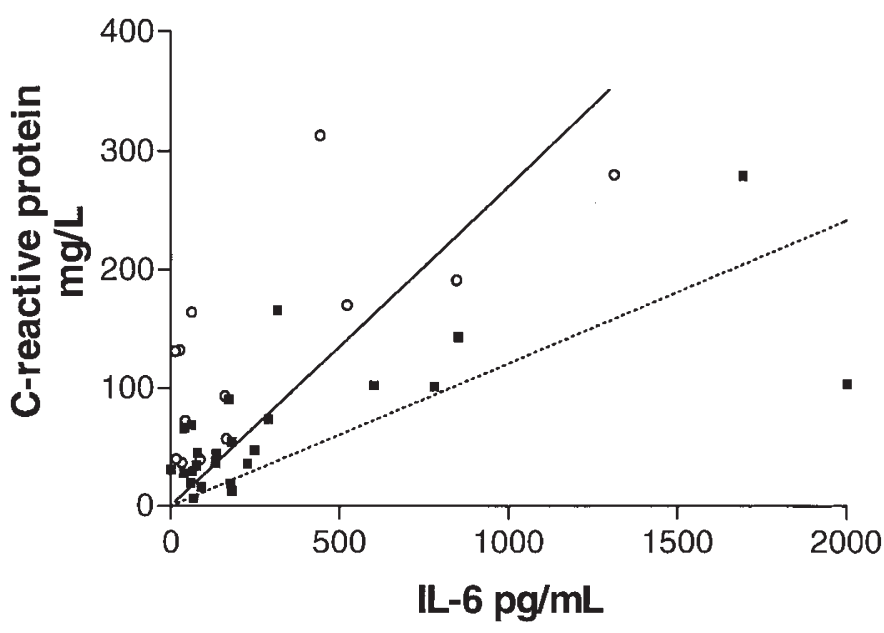

Figure 2. Correlation between serum IL-6 concentration and C-reactive protein for two groups of children with acute infection, well-nourished and marasmic. The correlations between IL-6 and C-reactive protein for both groups of children are highly significant (well-nourished children $r=0.82, p$ $<0.001$; marasmic children $r=0.85, p<0.001$ ). The slope of the relationship between C-reactive protein and IL-6 for the well-nourished children was greater than it was for marasmic children $(0.27,95 \%$ confidence intervals $0.17-0.39$ vs $0.12,95 \%$ confidence intervals $0.09-0.15)$. $\square$, Marasmic; $\bigcirc$, Well-nourished.

and leucine oxidation also suggest that nutritional status modulates protein kinetics.

The rates of leucine derived from whole-body proteolysis and nonoxidative leucine disposal in all marasmic children are similar; no catabolic response to acute infection is seen. However, acute infection does prompt some acute-phase response in marasmic children, as evidenced by the increased serum concentrations of acute-phase proteins. Therefore, we speculate that this is achieved by further suppression of visceral protein synthesis.

The well-nourished children with acute infection produced a vigorous acute-phase response, as indicated by the total acutephase protein concentrations and the changes in concentration that were observed in the first $24 \mathrm{~h}$. The IL-6 response to acute infection abated quickly in the well-nourished children. The marasmic children with acute infection did not produce a vigorous acute-phase response and had prolonged elevated concentrations of IL-6. The elevation in C-reactive protein among those with marasmus and infection compared with uninfected marasmic children and the direct correlation between IL-6 and several acute-phase proteins indicates that there was an attenuated acute response in severe malnutrition. This suggests that acute-phase response during malnutrition is limited by protein synthesis rather than by abnormalities in the cytokine cascade, which is consistent with the leucine kinetic data. In vitro production of IL-6 and TNF- $\alpha$ is reduced in severe malnutrition (18). This observation leads us to speculate that it could be diminished clearance of IL-6 that results in greater serum concentrations in severe malnutrition. In addition, IL- $1 \beta$ is known to stimulate IL-6 synthesis (19), and the direct correlation between the concentrations of the two cytokines found in this study support the notion that higher concentrations of IL- $1 \beta$ may be stimulating IL-6 synthesis in malnourished children.
A new observation from our work is that the IL- $1 \beta$ concentration is increased in the serum of malnourished children with and without acute infection. The low concentration seen in well-nourished infected children is consistent with data from other reports $(20,21)$, as this cytokine is known to be only transiently elevated during acute infection. Certainly subclinical exposure to pathogens, through either the gastrointestinal tract or other compromised portals, could explain the increased concentrations seen in uninfected children. It is known that essential fatty acids have immunomodulatory functions (22) and that increased dietary intake of $n-3$ polyunsaturated fatty acids can decrease cytokine production $(23,24)$. Although we did not assess the essential fatty acid status of these malnourished children, they may well have some degree of deficiency. We speculate that this may be related to the increased concentrations of IL- $1 \beta$ observed in both acutely infected and uninfected malnourished children whom we studied. Alternatively, the IL- $1 \beta$ may be in an inactive form or released during cell lysis. Further study is needed to determine the role that IL- $1 \beta$ plays in severe malnutrition.

Our findings are consistent with Morlese et al. (25), who explored the kinetics of specific acute-phase proteins in marasmic Jamaican children during and after an acute infection. They found that the concentrations of four acute-phase proteins were higher during acute infection, as was the absolute synthesis rate of haptoglobin, indicating that there was some acute-phase response in marasmic children. However, no wellnourished, infected control subjects were receiving the same diet in this Jamaican study, so it was not clear to what extent that malnutrition attenuated the acute-phase response.

This work, coupled with our recently published work comparing energy expenditure in these children (12), indicates that severe malnutrition suppresses the normal metabolic response to acute infection. Malnutrition blunts increases in protein turnover and with it the acute-phase response and limits increases in energy expenditure that facilitate fever. During malnutrition, nutrients are in short supply; perhaps this blunted metabolic response is an adaptation to conserve protein and energy. However, fever and the acute-phase protein response are known to be important components of a successful immune response to infection. Thus, it may be that this metabolic adaptation to malnutrition contributes to the immunocompromise of malnutrition. This speculation raises another question: if nutrients are not made available from endogenous stores to facilitate the immune response, then can dietary provision of these nutrients during malnutrition and infection enhance the immune the response? Would these malnourished, infected children fare better if more dietary protein and energy were provided? This question needs further investigation, and may provide an avenue to improve therapy to many unfortunate children who both are malnourished and have infection.

\section{CONCLUSIONS}

The rates of leucine derived from whole-body proteolysis and nonoxidative leucine disposal are lower in marasmic, infected children when compared with well-nourished, infected children and are similar to those in uninfected marasmic 
children. The concentrations of acute-phase proteins are lower in infected, marasmic children when compared with wellnourished infected children, but the serum cytokine concentrations are higher. Thus, the protein metabolic and acute-phase responses to acute infection are blunted in marasmus. Dietary interventions should be investigated to determine how they affect protein metabolism in malnutrition and infection.

\section{REFERENCES}

1. Scrimshaw NS, SanGiovanni J 1997 Synergism of nutrition, infection and immunity: an overview. Am J Clin Nutr 66:464S-477S

2. Garlick PJ, Reeds PJ 2000 Proteins. In: Garrow JS, James WPT, Ralph A (eds) Human Nutrition and Dietetics. Churchill-Livingstone, Edinburgh, pp 77-96

3. Soares MJ, Piers LS, Shetty PS, Jackson AA, Waterlow JC 1994 Whole body protein turnover in chronically undernourished individuals. Clin Sci 86:441-446

4. Long CL, Jeevanandam M, Kim BM, Kinney JM 1977 Whole body protein synthesis and catabolism in septic man. Am J Clin Nutr 30:1340-1344

5. Gabay C, Kushner I 1999 Acute-phase proteins and other systemic responses to inflammation. N Engl J Med 340:448-454

6. Szalai AJ, Briles DE, Volanakis JE 1995 Human C-reactive protein is protective against fatal Streptococcus pneumoniae infection in transgenic mice. J Immunol $155: 2557-2563$

7. Matthews DE, Motil KJ, Rohrbaugh DK, Burke JF, Young VR, Bier DM 1980 Measurement of leucine metabolism in man from a primed, continuous infusion of L- $\left[1-{ }^{13} \mathrm{C}\right]$ leucine. Am J Physiol 238:E474-E479

8. Wellcome Trust Working Party 1970 Classification of infantile malnutrition. Lancet 2:302-303

9. Briend A, Golden MHN 1993 Treatment of severe childhood malnutrition in refugee camps. Eur J Clin Nutr 47:750-754

10. World Health Organization 1999 Management of Severe Malnutrition: A Manual for Physicians and Other Senior Health Workers. World Health Organization, Geneva

11. Manary MJ, Yarasheski KE, Broadhead RL 2002 Urea production and leucine oxidation in malnourished children with and without infection. Metabolism 51:14181422
12. Manary MJ, Yarasheski KE, Berger R, Broadhead RL $2004 \mathrm{CO}_{2}$ production during acute infection in malnourished Malawian children. Eur J Clin Nutr 58:116-120

13. Yarasheski KE, Zachwieja JJ, Gischler J, Crowley J, Horgan MM, Powderly WG 1998 Increased plasma Gln and Leu Ra and inappropriately low muscle protein synthesis rate in AIDS wasting. Am J Physiol 275:E577-E583

14. Manary MJ, Brewster DR, Broadhead RL, Graham SM, Hart CA, Crowley JR, Fjeld CR, Yarasheski KE 1997 Whole-body protein kinetics in children with kwashiorkor and infection: a comparison of egg white and milk as dietary sources of protein. Am J Clin Nutr 66:643-648

15. Bodamer OA, Leonard JV, Tasker RC, Hoffmann GF, Halliday D 1997 Protein turnover in critically ill children. Eur J Pediatr 156:S59-S61

16. Reeds PR, Fjeld CR, Jahoor F 1994 Do the differences between the amino acid compositions of acute-phase and muscle proteins have a bearing on nitrogen loss in traumatic stress? J Nutr 124:906-910

17. Jahoor F, Gazzard B, Phillips G, Sharpstone D, Delrosario M, Fraser ME, Heird W, Smith R, Jackson A 1999 The acute phase protein response to human immunodeficiency virus in human subjects. Am J Physiol 276:E1092-E1098

18. Doherty JF, Golden MHN, Remick DG, Griffin GE 1994 Production of interleukin-6 and tumor necrosis factor- $\alpha$ in vitro is reduced in whole blood of severely malnourished children. Clin Sci 86:347-351

19. Parikh AA, Salzman AL, Fischer JE, Szabo C, Hasselgren PO 1997 Interleukin-1 beta and interferon-gamma regulate interleukin-6 production in cultured human intestinal epithelial cells. Shock 8:249-255

20. Strait RT, Kelly KJ, Kurup VP 1999 Tumor necrosis factor- $\alpha$, interleukin- $1 \beta$ and interleukin-6 levels in febrile, young children with and without occult bacteremia. Pediatrics 104:1321-1326

21. Harpaz R, Edelman R, Wasserman SS, Levine MM, Davis JR, Sztein MB 1992 Serum cytokine profiles in experimental human malaria. J Clin Invest 90:515-523

22. Calder PC, Yaqoob P, Thies F, Wallace FA, Miles EA 2002 Fatty acids and lymphocyte functions. Br J Nutr 87:S31-S48

23. Meydani SN, Lichtenstein AH, Cornwall S, Meydani M, Goldin BR, Rasmussen H, Dinarello CA, Schaefer EJ 1993 Immunologic effects of national cholesterol education step-2 diets with and without fish derived n-3 fatty acid enrichment. J Clin Invest 92:105-113

24. Kew S, Banerjee T, Minihane AM, Finnegan YE, Williams CM, Calder PC 2003 Relation between fatty acid composition of peripheral blood mononuclear cells and measures of immune cell function in healthy, free-living subjects aged $25-72 \mathrm{y}$. Am J Clin Nutr 77:1278-1286

25. Morlese JF, Forrester T, Jahoor F 1998 Acute-phase protein response to infection in severe malnutrition. Am J Physiol 275:E112-E117 